\title{
Assessment of the early-age compressive strength of concrete
}

\author{
Dorota Michałowska-Maziejuk ${ }^{1}$ Barbara Goszczyńska² \\ ${ }^{1}$ Department of Concrete Structures and Geotechnics; Faculty of Civil Engineering and Architecture; \\ Kielce University of Technology; 7 Tysiaclecia Państwa Polskiego Av., 25-314 Kielce, Poland; \\ d.michalowska@tu.kielce.pl (iD)0000-0002-8076-6836 \\ ${ }^{2}$ Department of Concrete Structures and Geotechnics; Faculty of Civil Engineering and Architecture; \\ Kielce University of Technology; 7 Tysiaclecia Państwa Polskiego Av., 25-314 Kielce, Poland; \\ b.goszczynska@tu.kielce.pl (D)0000-0003-2363-9141
}

Funding: This study was financed by the scientific and research work carried out as part of the statutory activity for years 2016 - 2018: "Analysis of the load-carrying capacity of reinforced concrete beams reinforced with CFRP composite materials, glued into the concrete cover" no. 02.0.06.00/2.01.01.01.0007; MNSP.BKWB.16.001.

Abstract: This paper analyses the results of concrete compressive strength tests on cubic samples with different w/c ratios during the early stage of hardening (at 7, 14, and 28 days). Statistical and strength parameters were assessed and the quality of the concrete was estimated. The expected concrete grade, $\mathrm{C} 25 / 30$, was confirmed against the formulation provided by the prefabrication plant. Then, the amount of individual constituents was adjusted to obtain the target grade of concrete, i.e., C20/25. The concrete grade was estimated based on concrete strength parameters measured at three time points and compared with the expected 28-day strength values determined as per Eurocode 2 and with the concrete grade defined by these values. The paper also provides an overview of the most widely used methods of testing concrete compressive strength.

Keywords: concrete, testing machine, concrete compressive strength, destructive method, water-cement ratio

\section{Introduction}

An important factor in the safety and use of structures in the rapidly developing construction industry is the assessment and control of quality and durability of materials used in buildings and engineering structures. When a structure is safe while being constructed and during its design service life, the requirements relating to its load-carrying capacity, stability, or use have been met [1]. One of the conditions of ensuring durability of a structure is to produce structural members of materials that maintain the strength and physical characteristics and general performance throughout the service period regardless of any changes in the 
purpose of a building, its reconstruction, expansion or external environmental influences [2]. Compromising the quality of materials raises maintenance costs and generates additional costs even before commissioning due to, for example, the necessity to strengthen structural and non-structural elements for improved load carrying capacity resulting from design and workmanship errors. Inadequate quality of materials in main components of a structure or its non-structural elements may be the cause of damage, faults, or, in worst cases, disasters.

Long term investigation of the causes of building accidents and disasters conducted by the Institute of Building Technology showed that in addition to random factors, such as strong winds, gas explosion, fire, or landslide, human errors in the design and construction of structures are critical. Poor quality of building materials adds to these factors greatly [3]-[5]. The most common errors occur during the material manufacturing process, or due to improper storage, transport and unloading, assembly, or finishing works.

According to Art. 62 of the Polish Construction Law [6], when renovating and modernising building structures, as well as during their service life, condition inspections must be performed periodically, and the conclusions and recommendations must be implemented.

It is also reasonable to control the materials used during the construction of buildings, especially when it comes to assessing their strength parameters and quality of workmanship. In case of concrete, the assessment of early-age strength parameters may be necessary:

- to make a decision about the removal of the supporting framework,

- to load structural members before initially planned date,

- to strengthen structural element in the event of insufficient load capacity due to errors, for example design errors,

- to confirm the compressive strength of concrete in case of design or construction errors,

- to resolve the doubts about the compliance of concrete strength with that determined on standardised test specimens.

Assessment of strength parameters and quality of building products used during and after the construction of a building is thus one of the fundamental issues in the diagnosis of building structures.

\section{Characterization of concrete strength assessment methods}

Concrete strength is one of the basic parameters defined in diagnostics of reinforced concrete structures. Diagnostic tests can be conducted in situ or in properly prepared laboratories. Generally, tests fall into three groups: non-destructive, semi-destructive, and destructive tests [7]. A detailed division of non- and semi-destructive tests used in concrete structure diagnosis, together with an original taxonomy of physical, chemical, and biological methods is discussed in [8].

Non-destructive testing (NDT) does not alter, damage or destroy the structure of the material tested. The most frequently used NDT techniques include ultrasonic and sclerometric methods. The ultrasonic test uses acoustic wave propagation velocity in the hardened concrete mix for predicting the strength of concrete. Measurement accuracy is related to the pulse frequency; the higher the frequency, the more accurate reading is obtained. The pulse generated by a transmitter placed on the surface of the test specimen travels through concrete along path $S$ with a known length. It is then transformed into an electrical signal by the receiver. The time $T$ of the wave pulse travel is measured. Knowing the path that the signal travelled, it is 
possible to calculate the velocity $V$ of the wave propagation $(V=\mathrm{S} / T)$. The indirect estimation of concrete strength $R$ is determined from the hypothetical $R$ - $V$ curve [9].

The second method of non-destructive testing is the sclerometric method, also known as the hardness test. Hardness is the resistance of the tested material to deformation caused by concentrated forces. It is most often measured with sclerometers, the so-called Schmidt hammers (Fig. 1) with different impact energies for specific applications.

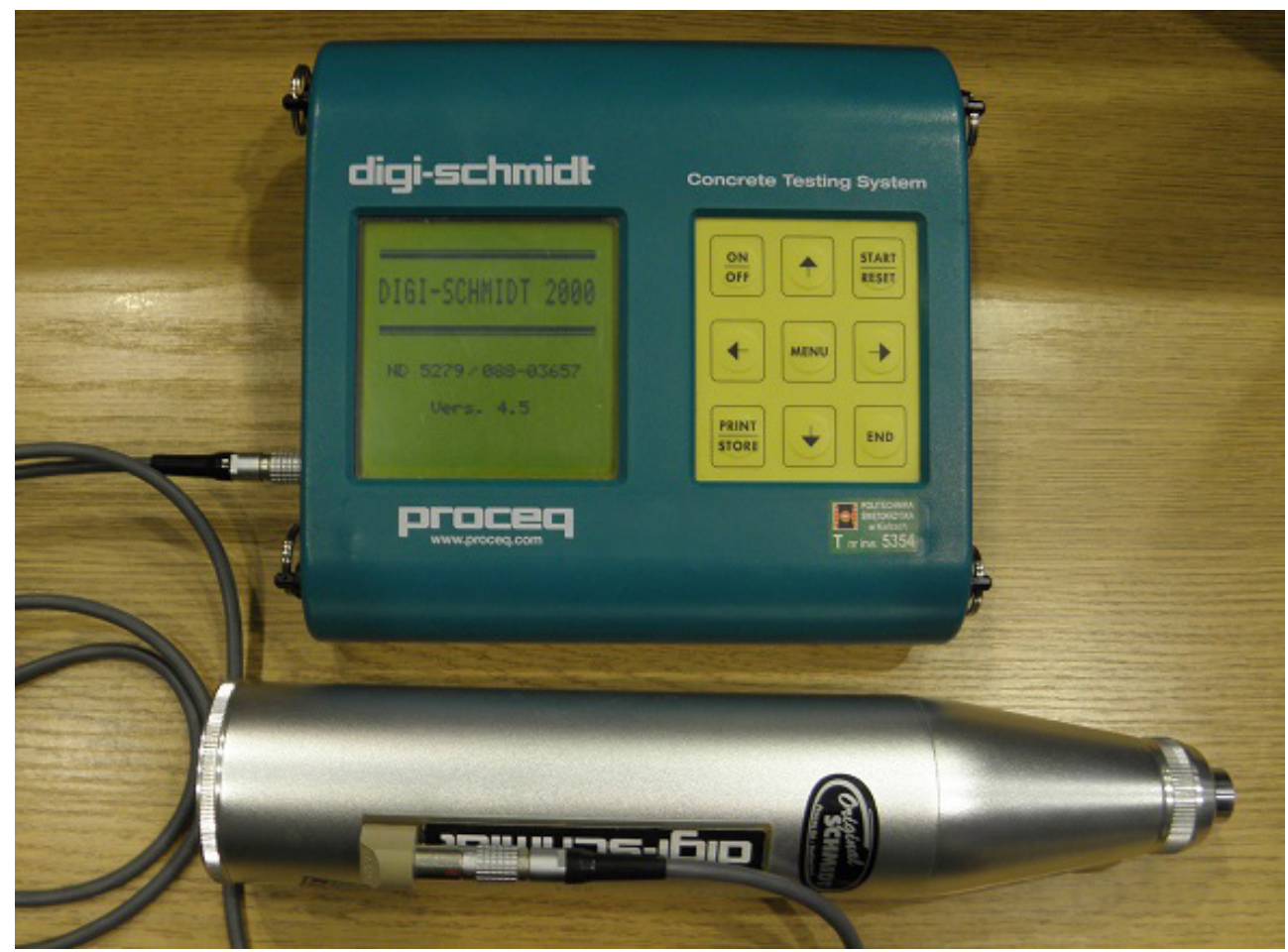

Fig. 1. Digital Schmidt hammer [10] (photograph by Dorota Michałowska-Maziejuk)

Hardness measurement involves pressing the plunger rod against the concrete surface until the spring-loaded mass releases and causes an impact. The degree of the rebound, measured against the calibration curves, is the rebound number $L$ which defines the compressive strength of concrete. The method is simple, the measurement can be repeated multiple times and the result is recorded automatically using the hammer as in Fig. 1. The week point of the rebound hammer test is that it tests the subsurface layer of concrete subject to carbonation (the formation of calcium carbonate $\mathrm{Ca}(\mathrm{OH})_{2}$ ). The ultrasonic method in contrast allows estimating the properties of concrete in its internal structure

Semi-destructive methods (SDM) comprise another group of tests. They are partially destructive in that they destroy elements of concrete surface to a limited extent. The most common SDMs are:

- the 'pull-out' method - it is based on pulling the blocks or anchors from hardened concrete, while measuring the force needed for them to be pulled out. This method 
is often used to determine the concrete strength gain over time, during the early phase of construction.

- the 'lock-out' method - is a variant of the pull-out method and is based on the measuring the force needed to pull out the steel anchors placed in the structure before concreting it.

- the 'pull-off' method - is based on measuring the force required to pull off a steel disc [11] glued to the surface of the tested element, which was earlier specially prepared and cut along its circumference. This technique is used when insulation or strengthening is to be added by drilling grooves in the concrete cover and filling them with the composite material or by gluing the composite on the concrete surface [12].

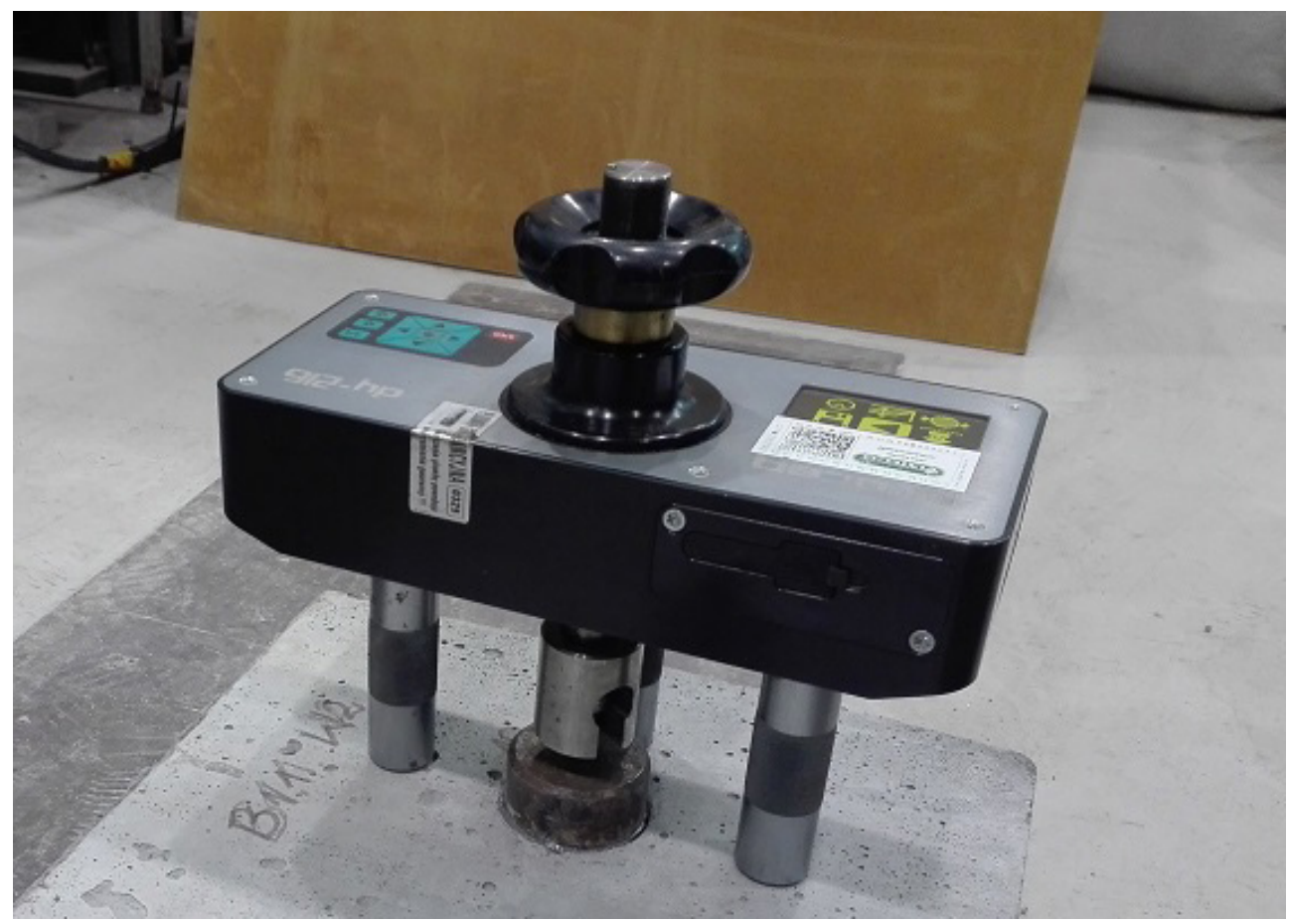

Fig. 2. A device used in the pull-off method (photograph by Dorota Michałowska-Maziejuk)

Destructive tests involve extracting witness samples from the existing structure and destroying them for strength characterisation. The axial compression test is applied for estimating the compressive strength of concrete. This method is based on the measurement of force needed to destroy the axially compressed sample, with the use of the strength testing machine in the research laboratory. Witness samples are extracted by coring or cast in separate moulds during the manufacture of concrete components. The cores used in the testing should be extracted from the areas which will not weaken the structure, that is, away from joints, edges, and main reinforcement. 
This article presents the test results obtained during axial compression and failure of concrete specimens. Analysis of the results allowed the evaluation of concrete grade and early-age quality.

\section{Testing programme}

The tests were carried out on cubic specimens with a side equal to $b=100 \mathrm{~mm}$ in the strength-testing machine at three concrete ages $\left(t_{1}=7\right.$ days, $t_{2}=14$ days, $t_{3}=28$ days $)$. An additional variable factor was the water-cement ratio obtained by changing the amount of cement at a constant amount of water used (Table 1). The test specimens were made of basalt aggregate based concrete grade $\mathrm{C} 20 / 25$. The concrete mix was poured into metal moulds and subjected to vibrations on a vibrating table [13]. The specimens were divided into four series, in which the water-cement ratio was the variable factor. The series designated as " 0 " was produced in order to verify the recipe for the $C 25 / 30$ road and bridge concrete provided by the prefabrication plant. Series $1 \div 3$ were made using the provided formulation, which was further modified to obtain concrete $\mathrm{C} 20 / 25$. For this purpose, the water-cement ratio was changed by 0.02 starting from $\mathrm{w} / \mathrm{c}=0.48$. The change in cement amount also caused a change in the number of admixtures used in the original formulation. Obtaining the expected grade of concrete was verified on the basis of the mean value of cylindrical compressive strength of concrete, which for concrete grade $\mathrm{C} 20 / 25$ is in interval $a \in<28 \div 33$ ) according to [1]. The concrete mix formulation for four series is presented in Table 1.

Table 1. The composition of the concrete mix is given in $\mathrm{kg}$ per $1 \mathrm{~m}^{3}$ batch

\begin{tabular}{llccc}
\hline Ingredients & Series 0 (S0) & Series 1 (S1) & Series 2 (S2) & Series 3 (S3) \\
\hline Basalt aggregate 8/16 & \multicolumn{3}{c}{731} \\
\hline Basalt aggregate 2/8 & \multicolumn{2}{c}{581} \\
\hline Sand 0/2 & & 691 & \\
\hline Water & 360 & 310 & 300 & 290 \\
\hline Cement CEM I 42,5R & 1.98 & 1.55 & 1.50 & 1.45 \\
\hline ADVA Flow 440 & 0.36 & 0.31 & 0.30 & 0.20 \\
\hline Darex AEA W & 0.42 & 0.48 & 0.50 & 0.52 \\
\hline w/c & & & & \\
\hline
\end{tabular}

The compression-testing machine, consisting of a hydraulic unit, a load frame and control and measurement electronics can generate a compressive force of $6000 \mathrm{kN}$. Readings are generated from the liquid pressure sensor. The tester measures and records the required test parameters, as well as performs statistical calculations and plots the relationships between the studied quantities [14].

After demoulding, loose debris was removed and the specimens were placed between the pressure plates of the press. Each time, the upper pressure plate was aligned centrally with the surface of the specimen owing to the ball joint connection with the load frame [15]. The specimens were continuously loaded until failure with a force perpendicular to the direction of concreting at $0.5 \mathrm{MPa} / \mathrm{s}$. After that, the samples were inspected visually and the typical failure pattern was confirmed [16]. The view of a typical failed concrete specimen is shown in Fig. 3, and Fig. 4. 


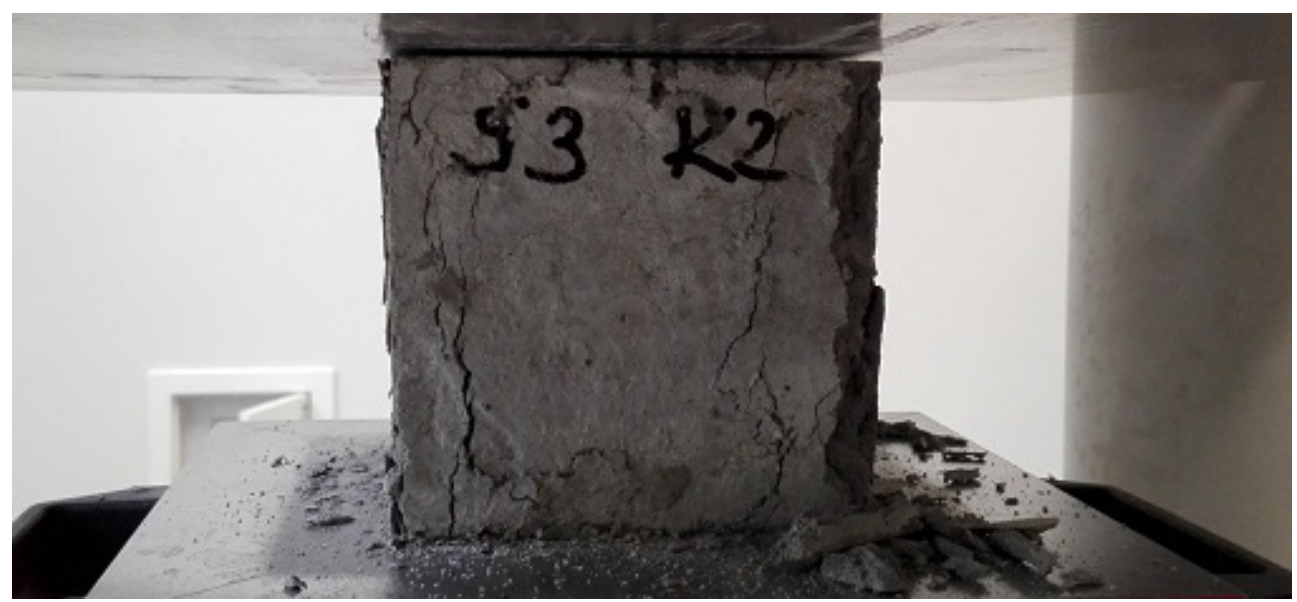

Fig. 3. Concrete specimen after compression test (photograph by Dorota Michałowska-Maziejuk)
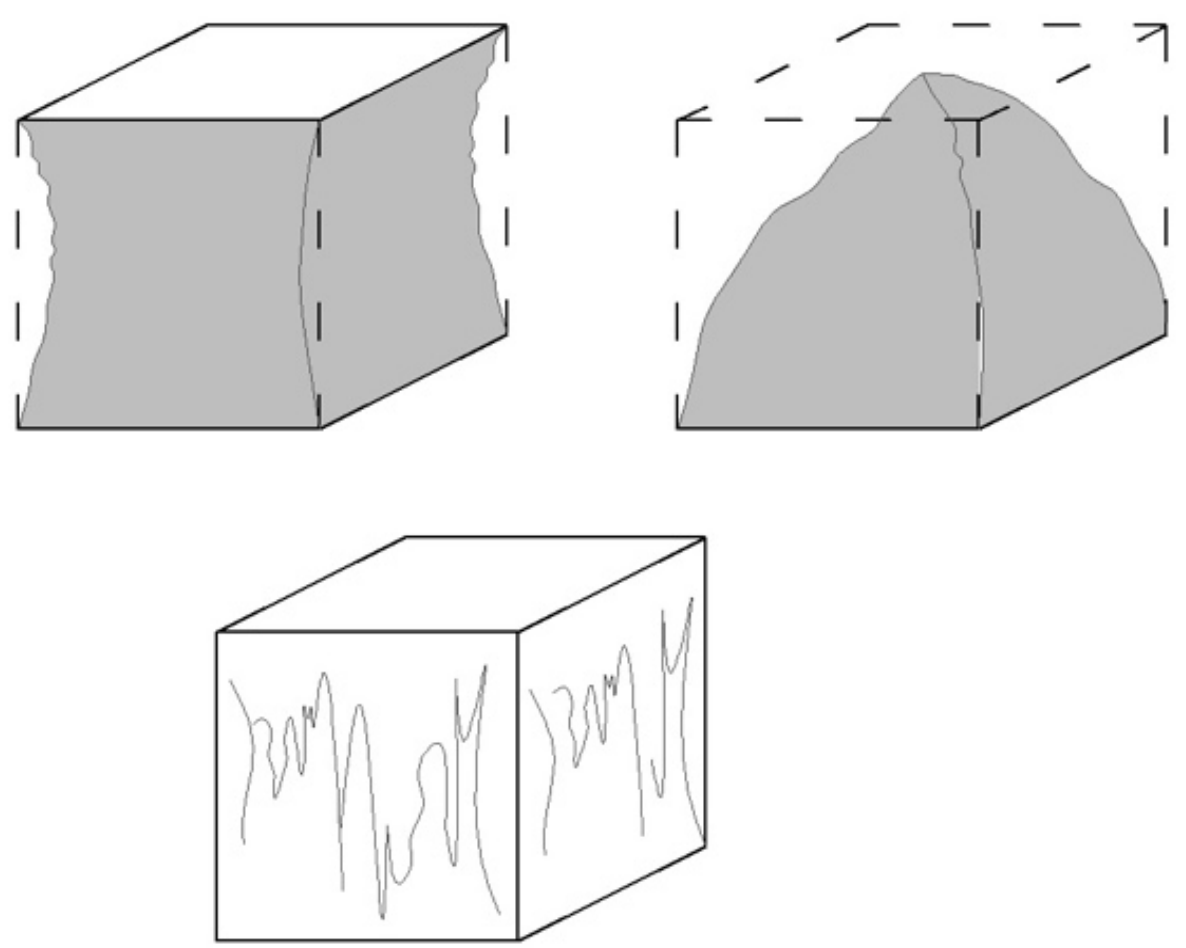

Fig. 4. Correctly damaged concrete specimen (illustration by Dorota Michałowska - Maziejuk)

The measurement of destructive forces of the test specimen series at three concrete ages with different water-cement ratios is summarized in Table 2 
Table 2. Results of measurements of destructive forces

\begin{tabular}{llllllllllll}
\hline \multicolumn{1}{l}{ Destructive force $[\mathrm{kN}]$} \\
\hline 7 days & \multicolumn{10}{c}{14 days } & \multicolumn{1}{c}{28 days } \\
\hline S0 & S1 & S2 & S3 & S0 & S1 & S2 & S3 & S0 & S1 & S2 & S3 \\
\hline 390.0 & 289.5 & 289.0 & 248.6 & 428.6 & 336.8 & 349.7 & 287.6 & 429.8 & 364.5 & 367.3 & 310.8 \\
\hline 324.9 & 303.1 & 305.9 & 240.5 & 411.7 & 341.7 & 347.2 & 278.8 & 426.3 & 361.8 & 359.9 & 318.9 \\
\hline 365.6 & 310.7 & 305.8 & 242.2 & 424.5 & 334.9 & 334.2 & 286.2 & 421.7 & 374.9 & 366.5 & 317.2 \\
\hline 368.9 & 313.6 & 295.2 & 249.6 & 374.4 & 364.8 & 342.7 & 291.4 & 397.3 & 364.6 & 379.4 & 315.6 \\
\hline
\end{tabular}

\section{Estimation of concrete grade and evaluation of statistical and strength parameters}

The first value needed for concrete grade estimation, compressive strength $f_{\mathrm{ci}}$ for each specimen series, was determined from equation (1) and expressed in $\mathrm{MPa}$ :

$$
f_{c i}=\frac{F_{i}}{A_{i}}
$$

where: $F_{\mathrm{i}}$ - maximum load on the $\mathrm{i}$-th specimen at failure, $A_{\mathrm{i}}-$ the area of the compression section of i-th specimen.

The mean value of the concrete compressive strength $f_{\mathrm{cm}}$ was calculated from equation (2):

$$
f_{c m}=\frac{1}{n} \sum_{i=1}^{n} f_{c i}
$$

where: $n$ - the number of results, $f_{\mathrm{ci}}$ - the individual result of concrete compressive strength for i-th specimen.

The measurements of strength values at three concrete ages for w/c ratios $0.42,0.48$, $0.50,0.52$ are shown in Table 3.

\begin{tabular}{|c|c|c|c|c|c|c|c|c|c|c|c|}
\hline \multicolumn{12}{|c|}{ Compressive strength $f_{\mathrm{c}}$ [MPa] } \\
\hline \multicolumn{4}{|c|}{7 days } & \multicolumn{4}{|c|}{14 days } & \multicolumn{4}{|c|}{28 days } \\
\hline S0 & S1 & S2 & S3 & S0 & S1 & $\mathrm{S} 2$ & S3 & S0 & S1 & S2 & S3 \\
\hline 39.00 & 28.95 & 28.90 & 24.86 & 42.86 & 33.68 & 34.97 & 28.76 & 42.98 & 36.45 & 36.73 & 31.07 \\
\hline 32.49 & 30.31 & 30.59 & 24.05 & 41.17 & 34.17 & 34.72 & 27.88 & 42.63 & 36.18 & 35.99 & 31.90 \\
\hline 36.56 & 31.07 & 30.58 & 24.22 & 42.45 & 33.49 & 33.42 & 28.62 & 42.17 & 37.49 & 36.65 & 31.72 \\
\hline 36.89 & 31.36 & 29.52 & 24.96 & 37.44 & 36.48 & 34.27 & 29.14 & 39.73 & 36.46 & 37.94 & 31.56 \\
\hline \multicolumn{12}{|c|}{ Mean compressive strength $f_{\mathrm{cm} .}$ cube cubic specimens [MPa] } \\
\hline 36.2 & 30.4 & 29.9 & 23.5 & 41.0 & 34.5 & 34.3 & 28.6 & 41.9 & 36.6 & 36.8 & 31.6 \\
\hline \multicolumn{12}{|c|}{ Mean compressive strength $f_{\mathrm{cm} .}{ }^{\text {cyl }}$ recalculated for cylindrical specimens[MPa] } \\
\hline 29.0 & 24.3 & 23.9 & 19.6 & 33.0 & 27.6 & 27.5 & 22.9 & 33.5 & 29.3 & 29.5 & 25.2 \\
\hline
\end{tabular}

Table 3. Compressive strength of the concrete specimens at 7, 14 and 28 days

When estimating the grade of the obtained concrete, the mean value of concrete cylinder compressive strength $f_{\mathrm{cm}}$ cyl was calculated in accordance with the rules [1] (Tab. 3). In the case of series S0, S1, and S2 with w/c ratios of $0.42,0.48$, and 0.50 respectively, more than $80 \%$ of the strength to be achieved at 28 days was obtained at the first seven days ( $\mathrm{S} 0-86 \%, \mathrm{~S} 1-83 \%$, and $\mathrm{S} 2-81 \%)$. For the series of three cubic specimens (w/c $=0.52), 77 \%$ of the concrete strength was 
obtained after 7 days. At 14 days in each of the above cases, over $90 \%$ of the concrete strength to be achieved in each series at 28 days was obtained (starting from $\mathrm{S} 0: 98 \%, 94 \%, 93 \%, 91 \%$ respectively). Percentage differences between the series are a result of different cement contents for the amount of mixing water used, which has a chemical effect in the concrete, causing hydrolysis and hydration of cement phases [17]. The smaller the cement content in relation to the constant amount of water, the lower the strength of the cement mix obtained at an age of 7, 14, and 28 days. The results of testing the $\mathrm{S} 0$ specimens made of concrete mix according to the composition provided by the prefabrication plant for concrete grade C25/30 confirmed achieving this grade already at an age of 14 days without changing it on the 28th day. The results of subsequent series of concrete specimens with a lower cement content relative to the constant amount of water showed that grade C20/25 was obtained at 28 days for series 1 and 2 (w/c ratio 0.48 and 0.50 , respectively). For series 3 , the results indicated concrete grade $\mathrm{C} 16 / 20$, which was lower than the target grade $\mathrm{C} 20 / 25$. The obtained results for series 3 specimens, together with the estimated concrete grade are shown in Table 4.

Table 4. Concrete grade obtained in the compression test

\begin{tabular}{lllllllll}
\hline Series 1 & \multicolumn{9}{c}{ Series 2} & \multicolumn{3}{c}{ Series 3} \\
\hline 7 days & 14 days & 28 days & 7 days & 14 days & 28 days & 7 days & 14 days & 28 days \\
\hline C12/15 & C16/20 & C20/25 & C12/15 & C16/20 & C20/25 & C $8 / 10$ & C12/15 & C16/20 \\
\hline
\end{tabular}

During statistical assessment of the homogeneity of concrete, first the value of variance $S^{2}$ was estimated, according to formula (3), and then the value of standard deviation $S$ was calculated from formula (4):

$$
\begin{aligned}
& S^{2}=\frac{1}{n-1} \sum_{i=1}^{n}\left(f_{c i}-f_{c m}\right)^{2} \\
& S=\sqrt{\frac{1}{n-1} \sum_{i=1}^{n}\left(f_{c i}-f_{c m}\right)^{2}}
\end{aligned}
$$

where: $n, f_{\mathrm{ci}}$ - as in formula (2), $f_{\mathrm{cm}}$ - mean compressive strength of concrete.

When determining the quality of concrete production, formula (5) was used, which is the relative standard deviation, called the coefficient of variation:

$$
v=\frac{S}{f_{c m}} 100 \%
$$

where: $S$ - standard deviation, $f_{\mathrm{cm}}$ - mean compressive strength of concrete.

The values of statistical parameters are compiled in Tables 5 and 6.

Table 5. Statistical evaluation of the results for series 0

\begin{tabular}{llll}
\hline & 7 days & 14 days & 28 days \\
\hline$s^{2}$ & 7.4 & 6.1 & 2.1 \\
\hline$s$ & 2.7 & 2.5 & 1.5 \\
\hline$v$ & $7.50 \%$ & $6.00 \%$ & $3.50 \%$ \\
\hline$v_{\text {sr }}$ & $5.70 \%$ & & \\
\hline
\end{tabular}


Table 6. Statistical evaluationof the results for series $1 \div 3$

\begin{tabular}{|c|c|c|c|c|c|c|c|c|c|}
\hline & \multicolumn{3}{|c|}{ Series 1} & \multicolumn{3}{|l|}{ Series 2} & \multicolumn{3}{|c|}{ Series 3} \\
\hline & 7days & 14 days & 28 days & 7 days & 14 days & 28 days & 7 days & 14 days & 28 days \\
\hline$s^{2}$ & 1.2 & 1.9 & 0.3 & 0.7 & 0.5 & 0.7 & 0.2 & 0.3 & 0.1 \\
\hline$s$ & 1.1 & 1.4 & 0.6 & 0.8 & 0.7 & 0.8 & 0.5 & 0.5 & 0.4 \\
\hline$v$ & $3.50 \%$ & $4.00 \%$ & $1.60 \%$ & $2.80 \%$ & $2.00 \%$ & $2.20 \%$ & $1.90 \%$ & $1.80 \%$ & $1.10 \%$ \\
\hline$v_{\text {sr }}$ & $3.03 \%$ & & & $2.33 \%$ & & & $1.60 \%$ & & \\
\hline
\end{tabular}

While determining the coefficient of variation of the test cubes results, it was found that quality of the obtained concrete mix was very good as confirmed by the relative mean standard deviation $v_{\text {sr }}$ of no more than $7 \%$ [9].

In order to estimate at $t_{1}=7$ days, $t_{2}=14$ days the mean strength of concrete that could be achieved at 28 days, the provisions of [1] were used, formula (6):

$$
f_{c m}(t)=\beta_{c c}(t) f_{c m}
$$

where: $\beta_{\mathrm{cc}}(t)$ - coefficient which depends on the age of the concrete $t$, expressed with formula (7), $f_{\mathrm{cm}}-$ mean compressive strength obtained at 28 days.

$$
\beta_{c c}(t)=\exp \left[s\left(1-\sqrt{\frac{28}{t}}\right)\right]
$$

where: $s$-coefficient depending on the type of cement, $t$ - the age of concrete expressed in days.

By transforming formula (6), the compressive strength $f_{\mathrm{cm}}$ of the concrete was calculated for two concrete ages, assuming the coefficient s equal to 0.20 . The concrete grade estimated and possible to to be achieved after 28 days, calculated at $t_{1}=7$ days and $t_{2}=14$ days for the components of the verified composition is C25/30, and for series 1 and 2 series, this will be grade 20/25. For the series 3 specimens it is grade C16/20. All of the estimated grades were equivalent to the concrete strength classes obtained in destructive testing. This confirms that current standard provisions are safe and correct. The concrete grade obtained during destructive tests and estimated on the basis of formula (6) agrees with the assumed grade C20/25 for series 1 and 2 , and $\mathrm{C} 25 / 30$ for series 0 . In series 3, the concrete grade was lower than assumed. The results of the estimated concrete grades at 28 days are shown in Table 7.

Table 7. Estimation from formula (6). Concrete grade after 28 days

\begin{tabular}{lllllllll}
\hline & Series 0 & & Series 1 & & Series 2 & & Series 3 \\
\hline$t$ [days] & 7 days & 14 days & 7 days & 14 days & 7 days & 14 days & 7 days & 14 days \\
\hline$\beta_{\text {cc }}(\mathrm{t})$ & 0.82 & 0.92 & 0.82 & 0.92 & 0.82 & 0.92 & 0.82 & 0.92 \\
\hline$f_{\text {cm }}(28)$ & 35.41 & 35.62 & 29.73 & 29.95 & 29.21 & 29.85 & 23.96 & 24.85 \\
\hline Concrete grade & $\mathrm{C} 25 / 30$ & $\mathrm{C} 25 / 30$ & $\mathrm{C} 20 / 25$ & $\mathrm{C} 20 / 25$ & $\mathrm{C} 20 / 25$ & $\mathrm{C} 20 / 25$ & $\mathrm{C} 12 / 15$ & $\mathrm{C} 16 / 20$ \\
\hline
\end{tabular}

\section{Summary}

The compressive strength of cube specimens was evaluated with the destructive method in a strength testing machine used in structural diagnostics. Concrete strength can be evaluated at the early age of the concrete (during construction) as well as later, when in service, during its reconstruction, extension, or while strengthening structural members. 
The grade of the concrete manufactured in accordance with the composition provided by the prefabrication plant was the same as that designed. After the modification of the mix composition by weight, the grade in series 1 and 2 of the concrete specimens tested was consistent with grade C20/25, which was also confirmed through the procedure set forth in [1]. Concrete homogeneity in each case was very good. It can therefore be concluded that the provisions of the EC2 standard are formulated in the way that guarantees the correctness of the assessment of concrete strength of the constructed elements of a given structure, which ensures its safety and durability.

The strength and quality of concrete are undoubtedly two of the essential parameters checked in the diagnosis of concrete structures, as they determine the durability of both newly constructed and already existing structures. Failure to ensure proper strength and quality of concrete may lead to failures and construction disasters.

\section{References}

[1] PN-EN 1992-1-1:2008: Eurokod 2. Projektowanie konstrukcji z betonu. Część 1-1: Reguły ogólne, reguty dla budynków.

[2] PN-EN 1990:2004: Eurokod. Podstawy projektowania konstrukcji.

[3] Runkiewicz L., „Ocena trwałości i niezawodności elementów żelbetowych za pomocą metod nieniszczących", Materiały budowlane, 12/2005, no. 400.

[4] Runkiewicz L., „Zagrożenia, awarie i katastrofy konstrukcji budowlanych”, in Seminarium „,Wybrane problemy wzmocnień i zabezpieczeń konstrukcji żelbetowych”, Warszawa ITB, 18 January 2019 r.

[5] Runkiewicz L., „O błędach technicznych podczas remontów i modernizacji obiektów budowlanych", Inżynieria i Budownictwo, no. 6/2013.

[6] Ustawa z dnia 7 lipca 1994r., Prawo budowlane, Warszawa, Dz.U. z 2019r. poz. 2170.

[7] Nagrodzka-Godycka K., Badanie właściwości betonu i żelbetu w warunkach laboratoryjnych. Arkady, Warszawa 1999.

[8] Hoła, J., Bień, J., Sadowski, Ł., \& Schabowicz, K., "Non-destructive and semi-destructive diagnostics of concrete structures in assessment of their durability", Bulletin of the Polish Academy of Sciences. Technical Sciences, 63(1), 2015, pp. 87-96.

[9] Drobiec Ł., Jasiński R., Piekarczyk A., Diagnostyka konstrukcji żelbetowych. Metodologia, badania polowe, badania laboratoryjne betonu i stali. PWN, Warszawa 2010.

[10] Michałowska-Maziejuk D., Raczkiewicz W., „Zastosowanie metody niszczącej i nieniszczącej do oceny wytrzymałości betonu", in Różne aspekty jakości materiałów i procesów stosowanych w budownictwie, Wydawnictwo PŚk, Kielce 2015, T. 70.

[11] PN-EN 1542:2000: Pomiar przyczepności przez odrywanie.

[12] Łagoda M., Zalecenia dotyczace wzmacniania konstrukcji mostowych przez przyklejanie zbrojenia zewnętrznego. IBDIM, Warszawa 2002.

[13] PN-EN 12390-2:2001: Badania betonu. Część 2: Wykonywanie i pielęgnacja próbek do badań wytrzymałościowych.

[14] Michałowska-Maziejuk D., Teodorczyk M., „The use of a concrete testing machine as teaching equipment in engineering education", Aparatura Badawcza i Dydaktyczna, vol. 23, 2/2018, s. 55-61.

[15] PN-EN 12390-4:2001: Badania betonu. Część 4: Wytrzymałość na ściskanie. Wymagania dla maszyn wytrzymatościowych.

[16] PN-EN 12390-3:2002: Badania betonu. Część 3: Wytrzymałość na ściskanie próbek do badania.

[17] Piasta J., Piasta W.G., Beton zwykty. Dobór kruszyw, projektowanie betonu, trwałość betonu, odporność chemiczna i termiczna. Arkady, Warszawa 1994. 